\title{
ПРОЦЕСС ИНСТИТУАЛИЗАЦИИ СУННИТСКОЙ ОБЩИНЫ В ЛИВАНЕ С 1945 ПО 1990-е ГОДЫ
}

\begin{abstract}
Аннотация: Одной из особенностей ливанского общества является то, что сложная поликонфессиональная ситуация наложила отпечаток на его социильную организацию и политическую жизнь, в том числе и на функционирование партийной системы. Партии и общественные движения, как правило, формировались в рамках той или иной религиозной группы. Достаточно часто руководство партийной организацией и общиной осуществлялось одним и тем же лицом, что впрочем, не мешало возникновению и нескольких партий на базе одной конфессии. В научной литературе подробно рассмотрен вопрос институализации и развития шиитских политических партий (Хизбалла и Амаль). Вопрос же о суннитских политических объединений практически не рассматривается. Скорее всего, это связано с тем, что первые являются нестандартным явлением, а вторые - прошли более традиционный путь развития. Но без понимания политического развития суннитской общины невозможно рассмотреть конфессиональные проблемы, которые появляются в стране. Целью и задачей данной статьи является сравнительный анализ возникновения и развития с 1945 года по 1990 год трех основных суннитских партий - Хизб ат-Тахрир аль-Исламий, альДжамаа аль-Исламийа, аль-Ахбаш. Несмотря на то, что все эти партии образовались после обретения Ливаном независимости, они прошли совершенно разные пути развития. Основными методами стали теоритический анализ источников (партийные документы, программы, официальные заявления членов партии), индуктивный анализ, а также проведение своих собственных интервью с представителями партий. Практическим значением данного исследование является то, что противоречия между этими силами и конкуренция между ними помогают понять, почему суннитская община Ливана так и не смогла консолидироваться в единое иелое и осталась довольно фрагментированной. Таким образом, выводы, сделаные по итогам анализа могут быть применены в будущчих исследованиях, посвященных анализу конфессионализма и внутри-и межконфессиональных противоречий на уровне политических институтов.
\end{abstract} Abstract: One of specific features of the society in Lebanon is that complicated political and religious situation is reflected upon its social organization and political life, including functioning of the party system. Parties and public movements were usually formed within the frameworks of certain religious groups. Often the leadership in the party organization and community was by the same person, while several parties could be formed based upon one religious denomination. The scientific literature provides detailed analysis of the institutionalization of the Shite political parties (Hezbollah, Amal). The issue of Sunni political association was not sufficiently studied. It probably has to do with the fact that while the Shiite parties are non-standard, the Sunni parties followed a more traditional path of development. However, understanding of the political development of the Sunni community is necessary for evaluating religious problems in Lebanon. The goal of this article is to provide comparative analysis of formation of development of the three main Sunni parties in Lebanon (Hizb at-Taharror al-Islamy, Al-Jamaa al-Islamiya, Al-Ahbash). While all of them were formed after the Lebanon became independent, their ways of development differed. The main methods were theoretical analysis of sources (party documents, programs, official statements of part members), inductive analysis, interviewing party representatives by the author. The practical importance of this study is due to the fact that contradictions among these parties and competition among them allow one to understand why the Sunni community of Lebanon remained fragmented, and it never became consolidated. Therefore, the conclusions made as a result of the analysis may be applied in the future studies devoted to the analysis of confessionalism and internal and inter-confessional contradictions at the level of political institutions. Ключевые слова: Суннитская община, институализация, Ливан, конфессионализм, партийные списки, традиционные исламистские партии, салафитские движения, процесс модернизации страны, система традиционного лидерства, ливанские «зуама».

Keywords: Sunni community, institutionalization, Lebanon, confessionalism, party lists, traditional Islamic parties, traditional Islamist parties, Salaphite movements, process of state modernization, system of traditional leadership, Lebanese "Zuama". 
DOI: $10.7256 / 1811-9018.2014 .8 .12585$

При цитировании этой статьи сноска на доі обязательна

\section{Право и политика $8(176) \cdot 2014$}

И 3 всего политического разнообразия Ливана можно выделить следующие основные партии: Хизбалла и Амаль, которые представляют главным образом интересы шиитского населения; Катаиб, Ливанские силы, Свободное патриотическое движение, Национально-либеральная партия, Национальный блок выступают от имени христиан; сунниты в основном представлены партиями Мустакбаль, Хизб ат-Тахрир, аль-Джамаа аль-Исламийа, аль-Ахбаш; друзы - Прогрессивной социалистической партией. ${ }^{1}$

Лояльность «своей» партии в различных регионах и областях страны становится очевидной даже по внешним признакам. Оказавшись в том или ином регионе, можно видеть плакаты и фотографии, флаги и другую символику поддерживаемого здесь движения. Так, шиитские южные районы Бейрута пестрят фотографиями лидеров Хизбаллы и Амаль. Суннитские западные районы - фотографиями видных представителей Мустакбаля. Соответственно облик восточных частей ливанской столицы говорит о приверженности населения христианским партиям².

К сожалению, из-за наличия множества факторов, которье повлияли на институализацию ливанских суннитов, нельзя вывести ее единую типологию. Однако мы можем все-таки классифицировать их следуюшим образом:

1. Партийные списки - метод объединения традицұионных лидеров («зуама») для получения места в парламенте в независимом Ливане. По классификации Мориса Дюверже их можно отнести к парламентским партиям, в которых основная роль принадлежит депутатам, вокруг которых формируются партийные объединения.

2. Традиционные исламистские партии - непарламентские партии, так как изначально они формировались вне парламента.

3. Салафитские движения - также относятся к непарламентским.

Появление этих типов политических движений связано с двумя процессами: процессом модернизациии страны и контрмерами традиционных лидеров. Формирование нового неокрепшего государства также подготовило плодотворную почву для иностранного

\footnotetext{
${ }^{1}$ Мохов Н. Непреодолимый конфессионализм Ливана. // Азия и Африка сегодня, №6, 2008. С. 29.

2 В основном распределение населения в Ливане происходит именно по конфессиональному принципу. Исторически сунниты проживают на Севере страны, а шииты - на Юге.
}

влияния, а именно распространения исламистских партий, перекочевавших в страну или создавиих в ней свои отделения.

В данной статье речь пойдет в основном о традииионных исламистских партиях, так как в период c 1945 по 1990 г2. в суннитской общиине фактически только они имели наиболее внятную политическую программу и структуру (в отличие от партийных списков «зуама»), набирали все большую народную поддержку и оказывали все большее влияние на политику Ливана. Салафитские движения хотя и начали появляться уже с 1946 года, но только с конца 1980$x$ гг. начали обретать популярность. Однако ни одну из этих форм институализации нельзя не упомянуть, так как они слишком связаны друг с другом, а изменения в одной влечет изменения в другой.

Изначально в Ливане политические партии начали создаваться на основе системы традиционного лидерства.

Заим (ар. - лидер) - в общем плане политический лидер, возглавляющий определенную конфессиональную общину. Зачастую он может и не являться официальной политической фигурой, а быть «серым кардиналом», который обладает достаточной силой и властью, чтобы манипулировать чиновниками и лоббировать принятие необходимых политических решений. Подобный феномен можно встретить едва ли не в любом слабо модернизированном обществе (впрочем, до некоторой степени, и в современном тоже). Всякий раз для него характерны: передача власти и должностей по наследству, ограничение влияния лидеров небольшими регионами, их хорошая материальная обеспеченность и т.п. Однако в Ливане были и свои особенности. Так, ливанские «зуама» широко использовали насильственные методы распространения влияния. Поначалу, многие из них имели у себя в подчинении так называемых «кабадайат» (дословно «вышибалы»), которые, вопервых, выполняли функцию телохранителей, а, вовторых, противодействовали оппонентам и следили за тем, чтобы во время выборов за их начальников голосовали. В итоге это привело к появлению у крупных семей своих собственных милиций, которые участвовали в гражданской войне.

Таким образом, с момента обретения независимости и с окончанием гражданской войны политическая система Ливана должна рассматриваться в основном через призму покровительства влиятельных семей и кланов, которая сохранялась в той или иной форме на протяжении порядка ста лет. 
Суннитская община исторически обладала намного большими правами и возможностями, чем шиитская. Это наблюдалось как в рамках политической системы, так и на уровне реальной политики. Например, во время французского мандата были созданы Высший исламский совет, который возглавлял Великий муфтий, и Управление вакфами. Эти институты просуществовали в качестве управляющих политических сил вплоть до середины 1980-х годов. Французы также создали местные Департаменты вакфов, которые занимались социальной политикой в регионах (управление больницами, школами, мечетями и т.п.). Руководящие должности в них занимали сунниты. Также эти департаменты управляли фондами, на средства которых содержались соответствующие социальные институты. Финансирование же фондов осуществлялось частично через пожертвования, а частично на средства, вырученные от управления собственностью, переданной им во владение. ${ }^{3}$

Следующим преимуществом суннитов, можно считать, что Муфтий Ливана (суннит) считается чиновником в ранге министра в аппарате Председателя Совета министров. Благодаря такому положению муфтий республики и возглавляемый им муфтият служат как бы промежуточным звеном между государством и мусульманской общиной (прежде всего суннитской).

Такая приближенность к органам государственной власти должна была способствовать дополнительному усилению суннитов, т.к. муфтий мог решать вопросы общины, используя свое реальное политическое влияние. Однако исторически сложилось так, что реальный эффект оказался прямо противоположенным. В конечном счете, среди простых верующих, особенно из бедных слоев, населения авторитет религиозного главы оказался под сомнением из-за его принадлежности к государственной номенклатуре. Его стали причислять к коррупционному бюрократическому аппарату. Эту критику удачно подхватывают отдельные местные муфтии или имамы для привлечения большего количества сторонников в суннитской среде, что приводит общину к все большей разобщенности 4 . Такая ситуация также стала плодотворной почвой сначала для появления

\footnotetext{
${ }^{3}$ http://www.ghazi.de/muslims.html

${ }^{4}$ Тут можно опять привести примеры других арабских стран, например Египта, Туниса, где религиозные деятели при более активном взаимодействии с государством начинали терять народную поддержку. Причина достаточна проста - они становились частью государственного аппарата, который подвержен таким явлениям, как бюрократия, коррупция и т.п.
}

радикальных исламистских группировок, а в дальнейшим для роста их популярности. Распространение их влияния осуществлялось в местах расселения суннитов, а именно в таких городах, как Триполи, Аккар, Динние, где трудные экономические условия жизни и неэффективные институты государственной власти играли на руку исламистам. «Зуама» также не могли полностью обеспечить решение всех проблем регионов, так как, во-первых, у них просто не хватало средств для этого, а, во-вторых, они скорее представляли из себя, скорее зажиточных феодалов, которые традиционно в первую очередь заботились о своем собственном благосостоянии. В этом как раз проявляется еще одна особенность ливанского общества в плане его отношения к политическим организациям. Зачастую для населения Ливана основным вопросом в выборе стороны является именно социальная политика, которую она проводит, как она решает экономические проблемы в условиях реальной политики. Идеология же уходит на второй план.

При том, что «зуама» существовали во всех конфессиональных общинах, именно у суннитов система традиционного лидерства была более эффективной, потому что сунниты были более активны в политическом плане (конкурентная среда между суннитскими политиками была намного выше в связи с их количеством и развитостью). Шиитская же община, имея более слабых и малочисленных лидеров, будучи менее политически активной и более маргинализованной, просто не имела необходимого ресурса для создания эффективных политических организаций.

Однако, важно то, что суннитские зуама не спешили до конца модернизировать исторически сложившуюся систему традиционного лидерства. С одной стороны, они начали трансформироваться под обновленную политическую систему Ливана - признали и начали участвовать в выборах в новые государственные органы (такие как Парламент и т.п.), но, с другой, «зуама» не запустили процесс институализации на базе своего окружения. Его, в свою очередь, начали исламистские движения.

Такая ситуация неудивительна, т.к. в независимом Ливане уже только представительство в органах власти обеспечивало преимущества элите, давая ей рычаги управления не только экономической и социальной жизнью, но и давала прямой доступ к законодательной и исполнительной власти.

В общем виде конфессиональное распределение мест в ливанском Парламенте до 1990 года выглядело следующим образом: 
DOI: $10.7256 / 1811-9018.2014 .8 .12585$

При цитировании этой статьи сноска на ооі обязательна

\section{Право и политика $8(176) \cdot 2014$}

\begin{tabular}{|c|c|}
\hline Конфессия & Перед Таифскими соглашениями \\
\hline Марониты & 30 \\
\hline Православные & 11 \\
\hline Католики & 6 \\
\hline Армяне ААЦ & 4 \\
\hline Армяне католики & 1 \\
\hline Протестанты & 1 \\
\hline Другие христиане & 1 \\
\hline Всего христиан & 54 \\
\hline Сунниты & 20 \\
\hline Шииты & 19 \\
\hline Друзы & 6 \\
\hline Алавиты & 0 \\
\hline Всего мусульман & 45 \\
\hline Всего депутатов & 99 \\
\hline
\end{tabular}

Таблица 1 показывает, что большинство мест было закреплено именно за христианами-маронитами, далее шли мусульмане-шииты.

Более детальный анализ показывает, что во второй половине XX века черты, характерные традиционному лидерству, наложили большой отпечаток на парламентскую систему. Речь идет в основном о принципе наследственности, что доказывают следующие данные, относящиеся к этому периоду:

1. Парламент возглавляли 4 представителя семьи ас-Сольх (сунниты $)^{5}$.

2. Четверть членов Палаты депутатов, созванной в 1960 году, были потомками людей, которые были представлены в законодательных органах при французском мандате. В период с 1970 по 1980 годы Амин Джумейль (лидер Ливанской социал-демократической партии «Катаиб»), Дани Шамун (лидер Национально либеральной партии), Валид Джумблат (ли-

${ }^{5}$ Сами ас-Сольх (26 июля 1942 - 22 марта 1943), Риад ас-Сольх (25 сентября 1943 - 10 января 1945), Такиэддин ас-Сольх (21 июня 1973 - 31 октября 1974), Рашид ас-Сольх (31 октября 1974 - 24 мая 1975). дер Прогрессивно-социалистической партии) наследовали свои посты в соответствующих партиях от своих отцов.

3. В парламенте господствовали 294 семьи. 68 из них занимали места от 5 до 20 раз $^{6}$, три 16 раз, одно - 14 раз, пять - 13 раз, 111 - от двух до четырех раз и 115 - только по одному pasy $^{7}$.

4. В Аккаре, где большинство населения является суннитским, депутаты избирались только из семейств Аали, Раси, Марраби, Даггер ${ }^{8}$. Друзы были представлены Арсланами и Джумблатами 9 .

Таблица №1 показывает, что, несмотря на некоторое обновление членов парламента, в общем, его большинство занимали одни и те же люди.

\footnotetext{
${ }^{6}$ Христианская семья Аль-Хури избиралась в парламент 20 раз.

${ }^{7}$ Агавельян Ю.В. Государственность и парламентаризм в Ливане // Востоковедный сборник (выпуск второй). М., 2001, С. 6

${ }^{8}$ Семейства Аали, Раси, Марраби, Даггер являются суннитскими.

${ }^{9}$ Шайрян Г.С. Этноконфессиональные конфликты. Ливан // Межэтнические конфликты в странах зарубежного Востока. - М., 1991. - C. $114-115$
} 
DOI: $10.7256 / 1811-9018.2014 .8 .12585$

При цитировании этой статьи сноска на doі обязательна

Антропология права

Таблийа №1

\begin{tabular}{|l|c|c|c|c|c|c|c|c|}
\hline & $\mathbf{1 9 4 3}$ & $\mathbf{1 9 4 7}$ & $\mathbf{1 9 5 1}$ & $\mathbf{1 9 5 3}$ & $\mathbf{1 9 5 7}$ & $\mathbf{1 9 6 0}$ & $\mathbf{1 9 6 4}$ & $\mathbf{1 9 6 8}$ \\
\hline $\begin{array}{l}\text { Новые члены } \\
\text { парламента }\end{array}$ & 31 & 22 & 45 & 12 & 26 & 52 & 29 & 28 \\
\hline $\begin{array}{l}\text { Общее Количество } \\
\text { депутатов }\end{array}$ & 55 & 55 & 77 & 77 & 77 & 99 & 99 & 99 \\
\hline $\begin{array}{l}\text { Процентное } \\
\text { соотношение (\%) }\end{array}$ & 52,6 & 40,0 & 56,3 & 27,3 & 39,4 & 52,0 & 29,3 & 28,3 \\
\hline
\end{tabular}

Что же касается суннитской общины в отдельности, то обновление в депутатских рядах касалось ее в меньшей степени. Парламент оставался монополией следующих семей: Сольх, Байхум, Дайк, Гхадур, Салам, Карами, Муккадам, Бизри и Жиср ${ }^{10}$.

Несмотря на непоколебимость традиционных черт ливанского общества, механизм системы выборов в парламент все-таки ограничивал единовластное правление отдельных семей. Весь Ливан делился на округа, которые можно грубо разделить на два типа: округа с однородным конфессиональным составом и поликонфессиональные округа. В первом случае борьба шла между различными представителями одной религиозной общины, а во втором - она обострялся еще и межконфессиональными разногласиями. Чтобы окончательно не расколоть общество, кандидатам приходилось вступать в коалиции (т.н. списки), которые и соперничали за представительство в Парламенте. Для примера можно привести несколько таких блоков - Национальный призыв, Нахдж. У них не было ни четкой организационной структуры, ни политической программы. Их цели сводились лишь к борьбе за власть и удовлетворение своих собственных интересов. Вследствие этого недовольство властью «зуама» среди простого населения начало возрастать. Это дало дополнительный импульс к еще большей популяризации исламистских движений.

В этой группе основными движениями стоит считать Хизб ат-Тахрир, аль-Джамаа аль-Исламийа, аль-Ахбаш. Однако только аль-Джамаа аль-Исламийа была официально зарегистрирована во второй половине XX века, Хизб ат-Тахрир только в 2006 году, а вот аль-Ахбаш до сих пор не получила официальной регистрации.

Созданная в Палестине Таки ад-Дином ан-Набхани в 1953 году ливанская Хизб ат-Тахрир организовалась раньше, чем остальные суннитские исламистские группировки. Однако в список официальных политических

${ }^{10}$ Zuwiyya J. The Parliamentary Election of Lebanon 1968. Netherlands, Leiden, 1972, p. 98. партий страны она была внесена лишь в 2006 году во время правительства Фуада Сенсоры. Количество членов партии не разглашается, о чем говорят официальные представители партии. Такая политика проводиться с целью обеспечения безопасности ее сторонников ${ }^{11}$.

Своей основной целью партия ставит переход к новому халифату. Он должен осуществляться в три стадии: 1. Культурная экспансии, которая заключается в привлечении новых членов партии, поддерживающих ее идеи и финальную цель.

2. Взаимодействие с неприсоединившейся частью мусульманской общины и дальнейшая экспансия. На этой стадии происходит постепенный процесс перехода к политической активности.

3. Создание государства, основанного на нормах ислама и шариата.

Данная концепция является основополагающей для Хизб ат-Тахрир, что не дает ей необходимой гибкости для активного участия в политической жизни Ливана. Эта жесткая позиция может быть также объяснена и непосредственной зависимостью ливанского филиала партии от головной организацией. Все основные решения принимаются в ее штаб-квартире, а остальные ячейки строго придерживаются обозначенной линии.

Следующей образовавшейся суннитской партией стала аль-Джамаа аль-Исламийа. На ней стоит остановиться подробнее, так как на сегодняшний день она является одной из крупнейших и наиболее популярных суннитских организаций.

Свои корни эта организация берет непосредственно от Братьев Мусульман. Основателем аль-Джамаа аль-Исламийа является Фатхи Якан.

Он родился в Триполи в 1933 году. В юном возрасте он познакомился с Мухаммедом Умаром ад-Даики, который на тот момент возглавлял им же созданную благотворительную организацию Джамаа Убада арРахман (араб. - Ассоциация сторонников сострадания).

\footnotetext{
${ }^{11}$ The Syrian Uprising in the Eyes of Lebanese Islamists // Al-Akhbar, http://english.al-akhbar.com/node/4683 [online: 22.04.2014]
} 


\section{Право и политика 8 (176) 2014}

По сути, она занималась лишь культурными и образовательными аспектами жизни мусульманской общины, не вовлекаясь в политические дела. В 1952 году Якан посещает ряд лекций и семинаров, которые проводил лидер сирийских Братьев Мусульман Мустафа асСибай ${ }^{12}$. Вдохновленный озвученными идеями он начал создавать идеологию своей партии. Для начала Якан пытался убедить ад-Даики расширить поле деятельности Джамаа Убада ар-Рахман, на что получил отказ и начал процесс создания политической партии, примером которой служили Братья Мусульмане. При фактической независимости ${ }^{13}$ ливанской партии, Фатхи Якан признавал Хасана аль-Банна как «вечного лидера, выдающегося исламского мыслителя XX века» ${ }^{14}$ и строго придерживался выработанной им идеологии. Однако, несмотря на такую приверженность, аль-Джамаа альИсламийа с самого начала позиционировала себя как обособленную организацию, а не крыло египетских Братьев Мусульман.

В итоге аль-Джамаа аль-Исламийа сформировалась в 1957 году, но официально была зарегистрирована 18 Июня 1964 года ${ }^{15}$. Организационно партия представляла следующую структуру - во главе стояло политбюро (которое возглавил Фатхи Якан) и различные отделения, занимающиеся социальными, политическими и т.д. вопросами.

Важно то, что партия с самого начала не отрицала политическую систему страны и стала активно взаимодействовать с некоторыми организациями, например, с официальными религиозными структурами - Дар альИфта (муфтият). Но из-за разразившейся гражданской войны в 1975 году, партия смогла принять участие в парламентских выборах только в 1992 году.

Практически с первых дней своего существования аль-Джамаа аль-Исламийа начинает широкую пропаганду. Первым шагом стало открытие отделения в Триполи. Уже с 1958 году в городе начинает вещание своя радиостанция - «Голос Свободного Ливана».

Параллельно запускаются благотворительные проекты, которые заключались в создании новых школ, больниц.

\footnotetext{
${ }^{12}$ Мустафа ас-Сибай - руководитель сирийской ячейки Братьев Мусульман.

${ }^{13}$ Имеются различные подходы к данной организации. Часть ученых считает ее автономной организацией, часть - ячейкой Братьев Мусульман.

${ }^{14}$ Якан Ф. Аль-Масала аль-Любнанийа мин Мантур Ислами. Бейрут, аль-Муасса аль-Исламий, 1979. с. 22.

${ }^{15}$ Абд аль-Гани И. Харакат аль-Исламия фи Любнан. Бейрут, альМарказ аль-Араби ли аль-Маалюмат, 2007. с. 110.
}

Далее в 1967 году была создана Джамаият атТарабия аль-Исламийа (ар. - Ассоциации Исламского Образования) ${ }^{16}$. Она стала благотворительной организацией со следующими целями:

1. Помощь нуждающимся слоям общества в получении доступа к образованию.

2. Создание образовательных учреждений различных ступеней. Например, на севере страны распространены школы под названием Мадарис альИман (ар. - Школы Веры).

3. Обеспечение населения бесплатным образованием.

4. Обучение истинным нормам шариата и преподавания Корана

5. Распространение культурных и религиозных ценностей.

С момента создания организации и до сегодняшнего дня было создано больше десятка школ и образовательных центров, которые в основном сосредоточены на севере страны.

Организовав собственные школы, партия пошла дальше по пути развития образовательной сферы страны и распространения своего влияния. На данный момент аль-Джамаа аль-Исламийа не организовала свои собственные высшие учебные заведения, а создала специальную организацию - Рабита ат-Туллаб аль-Муслимин (ар. - Лига мусульманских студентов), целью которой является помощь в адаптации и обучении студентов в различных ВУЗах.

Следующим сильным направлением социальной политики партии было обеспечение медицинской помощью. С этой целью был создан Всеобщий медицинский центр (середина 1960-х годов), который стал первой организацией в системе проекта Исламская медицинская ассоциация. Его целью является создание доступных медицинских центров, диспансеров на всей территории Ливана. Фактически же эти центры концентрируются в основном в суннитских районах.

Таким образом, мы видим, что с самого момента своего основания аль-Джамаа аль-Исламийа стала активно включаться в ливанскую политику, причем не отрицая ее явных конфессиональных реалий.

В отличие от такой гибкой политики другая суннитская политика аль-Ахбаш, не скрывая своего враждебного отношения к политической системе страны, проводила кардинально противоположную линию и не стремилась включаться в официальный политический процесс государства. Она была образована во время

${ }^{16}$ Уставные документы партии аль-Джамаа аль-Исламийа, Декрет № 222/Д. 
гражданской войны в Ливане (начало 1980-х годов) ${ }^{17}$. Партия также известна и под другим названием - Джамийат аль-Машари аль-Хайарийа аль-Исламийа (ар. - Ассоциация исламских благотворительных проектов). Идеологом Ассоциации и ее первым партийным лидером стал шейх Абдалла аль-Харрари (эфиопского происхождения). Но к реальной политической деятельности партия приступила только с приходом шейха Низара Халаби, который сформировал ее цельную идеологическую и организационную структуру.

Аль-Ахбаш с самого начала прочертила разграничительную линию между собой и другими исламистскими партиями. Лучше всего для ее описания подходят слова одного из руководителей партии - «целью нашей организации является распространение правильной религии для просвещения тех, кто был введен в заблуждение некорректным учением, например, пропагандируемым Братьями Мусульманами» ${ }^{18}$.

Официальные власти и остальные суннитские партии относились со скептицизмом к заявлениям и учению партии. В итоге Муфтият Ливана так и не одобрил регистрацию аль-Ахбаш и до сих пор она является неофициальным объединением.

Многие исследователи считают, что партия создала эклектичную доктрину, которая смешала в себе шиитские ${ }^{19}$, суннитские и суфийские принципы.

Правильный путь, как его определил Абдалла альХарари, включает в себя знание «науки о религии», компонентами которой являются ${ }^{20}$ :

1. Вера в Бога и его Пророка.

2. Правомерность хадисов и Сунны.

3. Знание атрибутов Бога, без антропоморфизма.

4. Знание отклонений от норм ислама, например, куфра.

5. Знание норм и правил истинного ислама.

Глубокое знание веры приходит не просто через чтение священного писания, но и через учение улемов. Поверхностное понимание текстов может привести к негативным результатам, таким, как появление экстремизма. Подчеркивая ключевую роль духовных

\footnotetext{
17 Если быть точным, то сама организация появилась еще 1930-х годах в Египте, а в 1950-х годах перекочевала в Ливан. Но вплоть до 1980-х годов партия не вела никакой пропаганды и политической деятельности.

${ }^{18}$ Moussalli A.S. Political Islam in Sunni Community of Lebanon // ISIM Newsletter 3/99, p. 25.

${ }^{19}$ Следует отметить, что аль-Ахбаш является суннитской партией, но в тоже время очень толерантна и терпима к шиитскому учению и его приверженникам.

${ }^{20}$ Manar al-Hudd, November 1992, p. 32.
}

лидеров, учение партии находит точки соприкосновения с институтом шиитских муджтахидов, одобряя систему власти «вилает аль-факих». Из суфийских идейаль-Ахбаш перенимает, например, учение о двух типах модернизации: плохой (имеются в виду те нововведения, которые неправильно трактуют Коран) и хорошей (приемлемые) $)^{21}$. Из суннитской политической мысли для партии ближе всего школы имамов аш-Шафийа, Малика и Ахмада ибн Ханбала ${ }^{22}$, в отличие от школ Сеййеда Кутба, Абд аль-Ваххаба, Фатхи Якана, Абадаллы Маудуди.

Правильное общество - общество стабильности, где социально- религиозный плюрализм является нормой для всех религиозных групп на всех уровнях общественной жизни. Поэтому аль-Ахбаш принимает систему политического конфессионализма Ливана.

Основные методы распространения идеологии, по мнению аль-Ахбаш должны носит ненасильственный характер ${ }^{23}$.

Аль-Ахбаш также как и другие партии проводит социальную политику - строительство школ, религиозных центров, мечетей и развитие спорта.

Как мы видим, к 1990 году уже сформировался ряд политических суннитских исламистских партий. В теории, будучи представителями суннитской общины, они должны быть нацелены на одну и туже цель - процветание Ливана и конкретно суннитской общины, но на практике получается, что эти партии не смогли объединиться для ее решения.

Для более ясного понимания причин такой фрагментарности общины рассмотрим схожие и отличительные черты этих трех организаций.

\section{Схожие черты:}

\section{1. Общеливанские вопросы:}

a. Каждой из организаций пришлось (а аль-Ахбаш до сих пор) действовать вне легального политического поля, т.к. они определенное количество времени не были официально зарегистрированы.

b. Создание исламского государства, опирающегося на истинные нормы шариата, т.к. современное общество видится им коррумпированным и отошедшим устоев исламского права ${ }^{24}$. Единствен-

\footnotetext{
${ }^{21}$ Ibidem.

${ }^{22} \mathrm{http} / / /$ www.aicp.org/index.php/about-aicp/english/1-what-is-theassociation-of-islamic-charitable-projects

${ }^{23}$ Gambill, Gary C. Lebanon: Liberation, Conflict, and Crisis. Palgrave Macmillan. P.33

24 Официальный сайт партии Хизб ат-Тахрир
} 


\section{Право и политика $8(176) \cdot 2014$}

ным исключением тут является Аль-Ахбаш, которая разделяет религию и политику.

c. Отмена политического конфессионализма (кроме Аль-Ахбаш).

\section{2. Религиозные вопросы:}

d. Ислам как всеобъемлющая система.

e. Источниками ислама являются Коран и Сунна.

f. Ислам актуален в любом месте в любой исторический период.

\section{3. Внешнеполитические вопросы:}

g. Противостояние Западу и Израилю.

\section{Отличительные черты:}

\section{1. Общеливанские вопросы:}

a. Способность к трансформации - аль-Джамаа альИсламийа и аль-Ахбаш не отрицали политические реалии поликонфессионального ливанского общества ${ }^{25}$.

b. Использование социальных проектов - на этом фронте преуспела только аль-Джамаа альИсламийа, для которой, в отличие от остальных партий, свойственна широкомасштабная благотворительная политика.

2. Религиозные вопросы:

c. Отношения к Джахилийи ${ }^{26}-$ Хизб ат-Тахрир, в отличие от остальных партий говорит о политике изоляции. Аль-Джамаа аль-Исламийа и альАхбаш считают, что без взаимодействия с этой частью общества невозможно дальнейшее распространение истинного Ислама.

Говоря о следующей группе суннитских организаций - салафитских движениях, надо учесть несколько аспектов:

1. Они не имеют официального статуса зарегистрированных партий.

2. Салафитов Ливана сложно назвать единой и цельной структурой, т.к. на данный момент по разным данным насчитывается около шести тысяч исламских объединений подобного рода.

3. В период до 1990 года суннитская община еще не до конца разочаровалась в традиционных лиде-

\footnotetext{
${ }^{25}$ Следует отметить, что схожесть в отношение с Джахилией и способность к трансформации не объединяет политические и идеологические взгляды Аль-Ахбаш и аль-Джамаа аль-Исламийа. Для Аль-Ахбаш они стали итогом неординарных идей своих идеологов. Аль-Джамаа альИсламийа пришла к ним вследствие активной политической деятельности, путем проб и ошибок.

${ }^{26}$ В данном контексте под Джахилией имеется в виду часть общества, которая отошла от истинных ном ислама.
}

рах и исламистских партиях, что делало салафитов непопулярными.

Несмотря на это, на современном этапе они пользуются все более широкой народной поддержкой и основные политические суннитские политические партии уже вынуждены блокироваться и считаться с их мнением. Поэтому следует кратко описать появление и развитие салафитского течения в независимом Ливане.

Салафитское движение появилось в Ливане еще в 1946 году, когда шейх Салем аш-Шахал создал альХарака ас-Салафийа. В XX веке, как и большинство салафистских объединений, оно представляла скорее социальное движение, не ставящее перед собой политических целей. Но уже в 1980-е годах эта организация включала в себя порядка 50 отдельных подразделений, которые в основном сконцентрировались на суннитском севере страны, а также имеют несколько отделений в Сайде и Бейруте. Другими словами, она крепко закрепилась на севере Ливана и уже могла претендовать на широкую народную поддержку благодаря своей социальной деятельности. На это указывают события 1980 года, когда Триполи управлялся как раз представителями этого движения. Это правлением было краткосрочным, до 1985 года, когда город был взят сирийскими вооруженными силами.

Существует мнение, что основное финансирование аль-Харака ас-Салафийа получает из Кувейта, где существует одноименная организация, которая, по всей видимости, является головной ${ }^{27}$.

Несмотря на всю разобщенность суннитских группировок, делались попытки создать единую платформу для этой общины. Гражданская война в Ливане смогла сплотить суннитов. Под руководством муфтия страны, шейха Хасана Халида, была создана организация Исламское объединение (атТажамма аль-Ислами) - собрание представителей суннитской общины, членами которого стали ее самые значимые фигуры. Например, туда входили - бывшие и действующие на тот момент премьерминистры, министры, депутаты, главы политических партий. На еженедельной основе проводились собрания, которые с помощью голосования принимали основные политические решения в рамках суннитской общины. Хотя организация просуществовала сравнительно недолго (с 1975 до 1989 года) и сталкивалась с рядом проблем (внутренние разногласия, отсутствие отлаженного механизма приня-

\footnotetext{
${ }^{27}$ Pall Z. Lebanese Salafis Between the Gulf and Europe: Development, Fractionalization and Transnational Networks of Salafism in Lebanon. Amsterdam University Press, 2013. Pp. 31-33.
} 
DOI: $10.7256 / 1811-9018.2014 .8 .12585$

При цитировании этой статьи сноска на doi обязательна

Антропология права

тия решений, отсутствие военизированного крыла), она стала очень важным объединением суннитов того времени. Вследствие этих проблем и сравнительно недолгого своего существования Исламское объединение смогло лишь стать открытой площадкой для представителей различных религиозных групп, поддерживающих идею поликонфессионализма. Оформиться в качестве партии с определенной структурой и идеологией ей не удалось.

К 1990 году в Ливане можно выделить три типа политических организаций, которые обладали своими характеристиками:

1. Партийные списки «зуама» - им несвойственны ни четкая структура, ни наличие идеологии. Целью их образование является получение депутатского мандата традиционными лидерами. Единственный пример - партия Мустакбаль, которую образовал заим - Саад Харири, но она выпадает из хронологических рамок статьи.

2. Традиционные исламистские партии - их основные задачи находятся вне парламентской борьбы. Участие же в ней расценивается в качестве инструмента достижения своих целей. По сравнению с первым типом они более структурированы и имеют четкую идеологию. В период с 1943 по 1990 год именно эти политические движения и партии обладали более менее четкой организационной структурой, идкологией и участвовали в государственной политической жизни.

3. Салафитские движения - также непарламентское, но, в отличие от исламистских партий, они уже совсем не стремились к участию в этом государственном органе.

Таким образом, суннитская община уже на момент формирования политических партий столкнулась с рядом проблем, часть из которых до сих пор не решена ${ }^{28}$ :

1. Отсутствие харизматичных лидеров. На протяжении истории независимого Ливана, можно назвать только несколько лидеров, которые пользовались поддержкой широкого круга суннитов (например, Риад ас-Сольх и Рафик Харири), остальные же являлись авторитетами только среди небольшого круга представителей общины.

2. Слабая консолидация. Эта проблема частично вытекает из первой. Разобщенность между об-

${ }^{28}$ Larkin P. The Inevitability of Identity: Lebanon, Nationalism and the Failure of an Idea. // The undergraduate Journal of Social Studies, Volume 1, Article 4. Pp. 2-6 щинными лидерами внутри суннитов не давала возможности общине выступать единым фронтом (в отличие, например, от шиитов и друзов).

3. Географические рамки. Вследствие слабой консолидации определенные суннитские лидеры могли распространить свое влияние лишь в отдельных округах, а не по всей территории расселения общины.

4. Потеря контроля над ситуацией. Из-за того что суннитские политические лидеры на протяжении практически 70 лет не могли договориться между собой (что удалось шиитам, друзам и христианам), общее положение суннитов в политической системе Ливана ослабло.

\section{Библиография:}

1. Gambill, Gary C. Lebanon: Liberation, Conflict, and Crisis. Palgrave Macmillan. P.33

2. Larkin P. The Inevitability of Identity: Lebanon, Nationalism and the Failure of an Idea. // The undergraduate Journal of Social Studies, Volume 1, Article 4.

3. Manar al-Hudd, November 1992, p. 32.

4. Moussalli A.S. Political Islam in Sunni Community of Lebanon // ISIM Newsletter 3/99.

5. Pall Z. Lebanese Salafis Between the Gulf and Europe: Development, Fractionalization and Transnational Networks of Salafism in Lebanon. Amsterdam University Press, 2013.

6. The Syrian Uprising in the Eyes of Lebanese Islamists // Al-Akhbar, http://english.al-akhbar.com/node/4683 [online: 22.04.2014]

7. What is the Association of Islamic Charitable Projects // Association of Islamic Project official website. http://www.aicp.org/index.php/about-aicp/english/1what-is-the-association-of-islamic-charitable-projects

8. Zuwiyya J. The Parliamentary Election of Lebanon 1968. Netherlands, Leiden, 1972.

9. Абд аль-Гани И. Харакат аль-Исламия фи Любнан. Бейрут, аль-Марказ аль-Араби ли альМаалюмат, 2007.

10. Агавельян Ю.В. Государственность и парламентаризм в Ливане // Востоковедный сборник (выпуск второй). М., 2001.

11. Мохов Н. Непреодолимый конфессионализм Ливана. // Азия и Африка сегодня, №6, 2008.

12. Мустафа ас-Сибай - руководитель сирийской ячейки Братьев Мусульман. 


\section{Право и политика $8(176) \cdot 2014$}

13. Шайрян Г.С. Этноконфессиональные конфликты. Ливан // Межэтнические конфликты в странах зарубежного Востока. М., 1991.

14. Якан Ф. Аль-Масала аль-Любнанийа мин Мантур Ислами. Бейрут, аль-Муасса аль-Исламий, 1979.

15. Ракитянский Н.М.. Рассмотрение исламского менталитета (политико-психологическое эссе) // Международные отношения. - 2014. - № 2. - С. 104-107. DOI: 10.7256/2305-560X.2014.2.11478

16. Мартыненко А.В. Основные тенденции развития интеллектуальной культуры ислама в Новое и Новейшее время // NB: Исторические исследования. - 2012. - № 1. - C.168-211. DOI: 10.7256/2306420X.2012.1.328. URL: http://e-notabene.ru/hr/ article_328.html

17. Хазиме С.М.. Подходы западных авторов к анализу суннитско-шиитских противоречий в странах Машрика (на примере Ирака, Ливана и Сирии) в начале XXI в. // Национальная безопасность / nota bene. - 2014. - № 2. - C. 104-107. DOI: 10.7256/20738560.2014.2.11273

18. Королева Л.А., Королев А.А., Молькин А.Н. Служители исламского культа в СССР в 1940-е гг. (по материалам Татарской АССР, Пензенской, Ульяновской и Куйбышевской областей) // NB: Исторические исследования. - 2014. - № 4. - С.95-119. DOI: 10.7256/2306-420X.2014.4.11951. URL: http:/ e-notabene.ru/hr/article_11951.html

19. Королева Л.А., Королев А.А., Молькин А.Н. Исламские политические и неформальные организации России 1990-х гг. (на примере Среднего Поволжья) // NB: Исторические исследования. - 2013. № 2. - C.76-88. DOI: 10.7256/2306-420X.2013.2.712. URL: http://e-notabene.ru/hr/article_712.html

20. Нурулла-Ходжаева Н.Т. Центрально-азиатский регион и его общинная культура: диалектика единства и многообразия // NB: Философские исследования. - 2014. - № 4. - C.68-91. DOI: 10.7256/2306-0174.2014.4.11806. URL: http://enotabene.ru/fr/article_11806.html

21. В.В Бубликов. Исламизация Европы как следствие дехристианизации и демографического кризиса // Тренды и управление. - 2013. - № 2. - С. 104-107. DOI: 10.7256/2307-9118.2013.2.5328

22. Кириллова А.И. Взаимодействие культур: интеграция, ассимиляция и воспитательная роль общества // NB: Проблемы общества и политики. - 2013. - № 1. - C.53-152. DOI: 10.7256/23060158.2013.1.319. URL: http://e-notabene.ru/pr/ article_319.html
23. Х.В. Дзуцев, Ю.Ю. Синелина. Распространение религиозного течения ваххабизм в республиках Северо-Кавказского Федерального округа Российской Федерации: этносоциологический анализ // Национальная безопасность / nota bene. - 2013. № 1. - С. 104-107. DOI: 10.7256/2073-8560.2013.01.9

24. Е. Н. Тамразова. Роль религии и права в становлении Арабского халифата // Политика и Общество. - 2012. - № 5. - C. 104-107.

25. Д.С. Рязанов. Представление о сущности "исламского государства" в книге Сайида Кутба "Вехи на пути" // Философия и культура. - 2011. - № 9. - C. 104-107

26. А. А. Кулагин Этническая и религиозная идентификация друзской общины // Исторический журнал: научные исследования. $-2012 .-2 .-$ С. $21-25$.

27. Н.В. Филина Факторы социально-политической привлекательности религиозных организаций // Политика и Общество. - 2013. - 2. - С. 168 - 175. DOI: 10.7256/1812-8696.2013.02.6.

\section{References (transliteration):}

1. Gambill, Gary C. Lebanon: Liberation, Conflict, and Crisis. Palgrave Macmillan. P.33

2. Larkin P. The Inevitability of Identity: Lebanon, Nationalism and the Failure of an Idea. // The undergraduate Journal of Social Studies, Volume 1, Article 4.

3. Manar al-Hudd, November 1992, p. 32.

4. Moussalli A.S. Political Islam in Sunni Community of Lebanon // ISIM Newsletter 3/99.

5. Pall Z. Lebanese Salafis Between the Gulf and Europe: Development, Fractionalization and Transnational Networks of Salafism in Lebanon. Amsterdam University Press, 2013.

6. Zuwiyya J. The Parliamentary Election of Lebanon 1968. Netherlands, Leiden, 1972.

7. Abd al'-Gani I. Kharakat al'-Islamiya fi Lyubnan. Beirut, al'-Markaz al'-Arabi li al'-Maalyumat, 2007.

8. Agavel'yan Yu.V. Gosudarstvennost' i parlamentarizm v Livane // Vostokovednyi sbornik (vypusk vtoroi). M., 2001.

9. Mokhov N. Nepreodolimyi konfessionalizm Livana. // Aziya i Afrika segodnya, №6, 2008.

10. Mustafa as-Sibai - rukovoditel' siriiskoi yacheiki Brat'ev Musul'man.

11. Shairyan G.S. Etnokonfessional'nye konflikty. Livan // Mezhetnicheskie konflikty v stranakh zarubezhnogo Vostoka. M., 1991. 
DOI: $10.7256 / 1811-9018.2014 .8 .12585$

При цитировании этой статьи сноска на doi обязательна

Антропология права

12. Yakan F. Al'-Masala al'-Lyubnaniia min Mantur Islami. Beirut, al'-Muassa al'-Islamii, 1979.

13. Rakityanskii N.M. Rassmotrenie islamskogo mentaliteta (politiko-psikhologicheskoe esse) // Mezhdunarodnye otnosheniya. - 2014. - № 2. - S. 104-107. DOI: 10.7256/2305-560X.2014.2.11478

14. Martynenko A.V. Osnovnye tendentsii razvitiya intellektual'noi kul'tury islama v Novoe i Noveishee vremya // NB: Istoricheskie issledovaniya. - 2012. № 1.-S.168-211.DOI: 10.7256/2306-420X.2012.1.328. URL: http://e-notabene.ru/hr/article 328.html

15. Khazime S.M.. Podkhody zapadnykh avtorov $\mathrm{k}$ analizu sunnitsko-shiitskikh protivorechii v stranakh Mashrika (na primere Iraka, Livana i Sirii) v nachale XXI v. // Natsional'naya bezopasnost' / nota bene. - 2014. - № 2. - S. 104-107. DOI: 10.7256/20738560.2014.2.11273

16. Koroleva L.A., Korolev A.A., Mol'kin A.N. Sluzhiteli islamskogo kul'ta v SSSR v 1940-e gg. (po materialam Tatarskoi ASSR, Penzenskoi, Ul'yanovskoi i Kuibyshevskoi oblastei) // NB: Istoricheskie issledovaniya. - 2014. - № 4. - S.95-119. DOI: 10.7256/2306420X.2014.4.11951. URL: http://e-notabene.ru/hr/article_11951.html

17. Koroleva L.A., Korolev A.A., Mol'kin A.N. Islamskie politicheskie i neformal'nye organizatsii Rossii 1990-kh gg. (na primere Srednego Povolzh'ya) // NB: Istoricheskie issledovaniya. - 2013. - № 2. - S.76-88. DOI: 10.7256/2306-420X.2013.2.712. URL: http://enotabene.ru/hr/article $712 . \mathrm{html}$

18. Nurulla-Khodzhaeva N.T. Tsentral'no-aziatskii region i ego obshchinnaya kul'tura: dialektika edinstva i mnogoobraziya // NB: Filosofskie issledo- vaniya. - 2014. - № 4. - S.68-91. DOI: 10.7256/23060174.2014.4.11806. URL: http://e-notabene.ru/fr/article_11806.html

19. V.V Bublikov. Islamizatsiya Evropy kak sledstvie dekhristianizatsii i demograficheskogo krizisa // Trendy i upravlenie. - 2013. - № 2. - S. 104-107. DOI: 10.7256/2307-9118.2013.2.5328

20. Kirillova A.I. Vzaimodeistvie kul'tur: integratsiya, assimilyatsiya i vospitatel'naya rol' obshchestva // NB: Problemy obshchestva i politiki. - 2013. - № 1. S.53-152. DOI: 10.7256/2306-0158.2013.1.319. URL: http://e-notabene.ru/pr/article_319.html

21. Kh.V. Dzutsev, Yu.Yu. Sinelina. Rasprostranenie religioznogo techeniya vakhkhabizm $\mathrm{v}$ respublikakh Severo-Kavkazskogo Federal'nogo okruga Rossiiskoi Federatsii: etnosotsiologicheskii analiz // Natsional'naya bezopasnost' / nota bene. - 2013. - № 1. - S. 104-107. DOI: 10.7256/20738560.2013.01.9

22. E. N. Tamrazova. Rol' religii i prava v stanovlenii Arabskogo khalifata // Politika i Obshchestvo. - 2012. - № 5. - S. 104-107.

23. D.S. Ryazanov. Predstavlenie o sushchnosti "islamskogo gosudarstva" v knige Saiida Kutba "Vekhi na puti” // Filosofiya i kul’tura. - 2011. - № 9. - S. 104107

24. A. A. Kulagin Etnicheskaya i religioznaya identifikatsiya druzskoi obshchiny // Istoricheskii zhurnal: nauchnye issledovaniya. -2012 . -2 . - C. $21-25$.

25. N.V. Filina Faktory sotsial'no-politicheskoi privlekatel'nosti religioznykh organizatsii // Politika i Obshchestvo. - 2013. - 2. - C. 168 - 175. DOI: 10.7256/1812-8696.2013.02.6. 